\title{
Medium-term soil pH and exchangeable aluminium response to liming at three high country locations
}

\author{
J.L. MOIR ${ }^{1}$ and D.J. MOOT ${ }^{2}$ \\ ${ }^{I}$ Department of Soil and Physical Sciences \\ ${ }^{2}$ Department of Agricultural Sciences \\ Lincoln University, PO Box 84, Lincoln, Canterbury \\ jim.moir@lincoln.ac.nz
}

\begin{abstract}
Acid soil conditions and associated aluminium (Al) toxicity pose a serious impediment to legume establishment, persistence and productivity in high country. However, data that report soil exchangeable Al concentrations in response to lime applications are scarce. Three historical (3-8-year-old) lime trial soils were sampled for soil $\mathrm{pH}$ and exchangeable aluminium (Al). Soil pH ranged from 4.8 to 7.5 , with exchangeable $\mathrm{Al}$ concentrations $\left(\mathrm{CaCl}_{2}\right.$ extraction) of 0.2 to $24 \mathrm{mg} \mathrm{Al} /$ $\mathrm{kg}$. Soil $\mathrm{pH}$ and exchangeable $\mathrm{Al}$ changed significantly when lime was applied, but the shape of the response differed between the three site locations. The soil $\mathrm{pH}$ changes $(0-7.5 \mathrm{~cm}$ horizon) were $0.16,0.10$ and 0.20 $\mathrm{pH}$ units/t lime applied. Critical research needs to be conducted to investigate the key soil factors and mechanisms that result in Al toxicity in high country soils to enable development of mitigation strategies. On-farm decisions on lime rates and legume species suitability need to be based on soil $\mathrm{pH}$ and $\mathrm{Al}$ testing from individual farm blocks rather than using "rule of thumb" approaches.
\end{abstract}

Keywords: soil $\mathrm{pH}$, soil exchangeable aluminium, lime, pasture legumes

\section{Introduction}

Many South Island high country soils have low soil $\mathrm{pH}$ and possibly high exchangeable $\mathrm{Al}$ concentrations. Soil acidity (low soil $\mathrm{pH}$ coupled with toxic concentrations of exchangeable aluminium) and low available phosphorus (P) and sulphur (S) may also limit establishment and maintenance of legumes (Moir et al. 2000; Haynes \& Williams 1993). To neutralise increased soil acidity, lime must be applied, and where this cannot be done economically, soils may be too acidic for legumes and productivity declines sharply (Edmeades et al. 1983; Lanyon \& Griffith 1988). Valuable dryland forages, such as lucerne (Medicago sativa L.), are intolerant of acid soil conditions and related aluminium (Al) toxicity (Rechcigl et al. 1988; Su \& Evans 1996). Often the cost of lime or its application is uneconomic in extensive high country regions. In many cases the rate of penetration of the effects of surface applied lime, and subsequent pasture response, are unknown. Incorporation of lime may be possible on flatter land but the risk of wind erosion means direct drilling is the preferred establishment technique. The relationship between pasture production and soil $\mathrm{pH}$ is well established on some high country soils and the critical concentrations of exchangeable Al (Haynes \& Williams 1993) and the relative Al tolerance of some forage legumes have also been examined (Edmeades et al. 1991; Wheeler et al. 1992). However, studies of soil $\mathrm{pH}$ changes with surface applied lime, and associated changes in soil exchangeable $\mathrm{Al}$ at the surface and at depth over time, in South Island high country soils are scarce.

Previously, Moir \& Moot (2010) reported on the effects of surface applied lime on lucerne in an acid high country soil. Horizontal, restricted, root growth related to Al toxicity issues were reported, along with soil $\mathrm{pH}$ and exchangeable $\mathrm{Al}$ changes resulting from lime applications. This paper updates results from a from this field experiment and also reports results from two additional established lime trials in the South Island high country. The aim of this study was to examine the effects of lime rate on $\mathrm{pH}$ and soil exchangeable aluminium concentrations of three acid high country soils at different locations.

\section{Methods}

\section{Site description and trial design}

Three historical lime field trials were examined. Site 1 was located at Mt Pember station, North Canterbury (Moir \& Moot 2010); Site 2 was Glenmore station, located on the southern banks of Lake Tekapo, central Canterbury; and Site 3 was Glenfoyle station, near Lake Hawea, Central Otago. Site specific information and treatment lime rates are presented in Table 1.

AgLime was surface applied at Site 1 in March 2008, followed by sowing of 'Grasslands Kaituna' lucerne . Further details of the Mt Pember Station experimental area are given by Moir \& Moot (2010) and Fasi et al. (2008). All plots were soil sampled to $15 \mathrm{~cm}$ depth in September 2013. Glenmore Station (Site 2) is a pasture experimental site (Moot \& Pollock 2014). AgLime was surface applied in replicate blocks $(20 \times 10 \mathrm{~m}$ plots; 2 
replicates) in October 2010 and soil samples $(30 \times 2.5$ $\mathrm{cm}$ cores; 0-15 cm deep) were taken in March 2013. Glenfoyle Station (Site 3) consists of $5 \times 10 \mathrm{~m}$ pasture plots on hill slopes with treatments replicated four times (Espie 2008). AgLime was surface applied in April 2005 and soil samples $(15 \times 2.5 \mathrm{~cm}$ cores; $0-15 \mathrm{~cm}$ or $0-7.5 \mathrm{~cm}$ deep in stony ground) taken in December 2012. All soil samples were analysed for $\mathrm{pH}(1: 2.5$ soil: water ratio) and exchangeable aluminium (0.02 $\mathrm{M} \mathrm{CaCl}$ extraction followed by inductively coupled plasma atomic emission spectroscopy (ICP-OES) analysis.

\section{Results}

\section{Lime effects on soil pH}

Soil $\mathrm{pH}$ differed with horizon depth and lime rate at all three sites. Five years after the initial lime application at Site 1 (Mt Pember Station), soil $\mathrm{pH}$ was higher at
0-7.5 cm than the 7.5 to $15 \mathrm{~cm}$, soil depths. The $\mathrm{pH}$ in the $0-7.5 \mathrm{~cm}$ horizon increased in a linear fashion with lime, to a maximum of 6.7 at $8 \mathrm{t}$ lime/ha (Table 2). In the $7.5-15 \mathrm{~cm}$ horizon, $\mathrm{pH}$ was unaffected by lime rate, except at $8 \mathrm{t} / \mathrm{ha}$, where it increased to 6.1. At Site 2 (Glenmore station), moderate increases in soil $\mathrm{pH}$ were observed in the $0-7.5 \mathrm{~cm}$ horizon three years after lime was applied, but not in the $7.5-15 \mathrm{~cm}$ horizon. At Site 3 (Glenfoyle Station), large increases in soil $\mathrm{pH}$ occurred in the $0-7.5 \mathrm{~cm}$ horizon in response to lime applications eight years after application. The maximum increase was $0.8 \mathrm{pH}$ units at $4 \mathrm{tlime} / \mathrm{ha}$. Only minimal increases in $\mathrm{pH}$ were observed with increasing lime rate for the $7.5-15 \mathrm{~cm}$ horizon at this site. In terms of soil $\mathrm{pH}$ change per unit of lime applied, changes for the 0-7.5 $\mathrm{cm}$ horizon were $0.16,0.10$ and $0.20 \mathrm{pH}$ units/t lime applied at Sites 1, 2 and 3 respectively.

Table 1 Site physical information and treatment lime rates for three historical high country field trials.

\begin{tabular}{lccccccc}
\hline \multicolumn{1}{c}{ Site } & Location & $\begin{array}{c}\text { Annual } \\
\text { Rainfall } \\
(\mathbf{m m})\end{array}$ & $\begin{array}{c}\text { Altitude } \\
(\mathbf{m} \text { a.s.l.) }\end{array}$ & Topography & Soil Group & Lime Rates (t/ha) \\
\hline 1: Mt Pember Station & North Canterbury & 600 & 430 & Flat & Stony Brown Soil & $0,2,4,8$ \\
2: Glenmore Station & Central Canterbury & 600 & 700 & Flat - rolling & Brown soil & $0,3,5$ \\
3: Glenfoyle Station & Central Otago & 600 & 750 & Hill & $\left(\mathbf{1 5 - 2 0 ^ { \circ } )}\right.$ & Dense brown hill soil & 0, 0.13, 0.25, 0.5, 2, 4 \\
\hline
\end{tabular}

Table 2 Soil $\mathrm{pH}$ and exchangeable Al values for three high country field trial sites at two soil horizon sampling depths (0-7.5 and $7.5-15 \mathrm{~cm})$.

\begin{tabular}{|c|c|c|c|c|c|}
\hline \multirow[t]{2}{*}{ Site } & \multirow[t]{2}{*}{ Lime Rate (t/ha) } & \multicolumn{2}{|c|}{$\mathrm{pH}$} & \multicolumn{2}{|c|}{ Exchangeable Al (mg/kg) } \\
\hline & & $0-7.5 \mathrm{~cm}$ & $7.5-15 \mathrm{~cm}$ & $0-7.5 \mathrm{~cm}$ & $7.5-15 \mathrm{~cm}$ \\
\hline \multirow[t]{5}{*}{ 1: Mt Pember Station } & 0 & 5.4 & 5.6 & 3.0 & 5.6 \\
\hline & 2 & 5.7 & 5.7 & 2.2 & 4.4 \\
\hline & 4 & 6.1 & 5.6 & 1.2 & 5.5 \\
\hline & 8 & 6.7 & 6.1 & 0.5 & 1.9 \\
\hline & sem & 0.09 & 0.12 & 0.20 & 1.40 \\
\hline \multirow[t]{4}{*}{ 2: Glenmore Station } & 0 & 4.9 & 5.3 & 5.0 & 5.1 \\
\hline & 3 & 5.5 & 5.2 & 2.2 & 5.9 \\
\hline & 5 & 5.4 & 5.2 & 2.6 & 4.9 \\
\hline & sem & 0.05 & 0.04 & 0.82 & 0.80 \\
\hline \multirow[t]{8}{*}{ 3: Glenfoyle Station } & 0 & 5.5 & 5.2 & 3.1 & 17.3 \\
\hline & 0.13 & 5.6 & 5.1 & 3.5 & 17.4 \\
\hline & 0.25 & 5.6 & 5.3 & 3.0 & 13.0 \\
\hline & 0.5 & 5.6 & 5.3 & 3.9 & 13.5 \\
\hline & 1.0 & 5.8 & 5.3 & 1.5 & 9.8 \\
\hline & 2.0 & 6.0 & 5.3 & 1.4 & 11.8 \\
\hline & 4.0 & 6.3 & 5.3 & 1.1 & 9.2 \\
\hline & sem & 0.11 & 0.03 & 0.90 & 0.91 \\
\hline
\end{tabular}


a

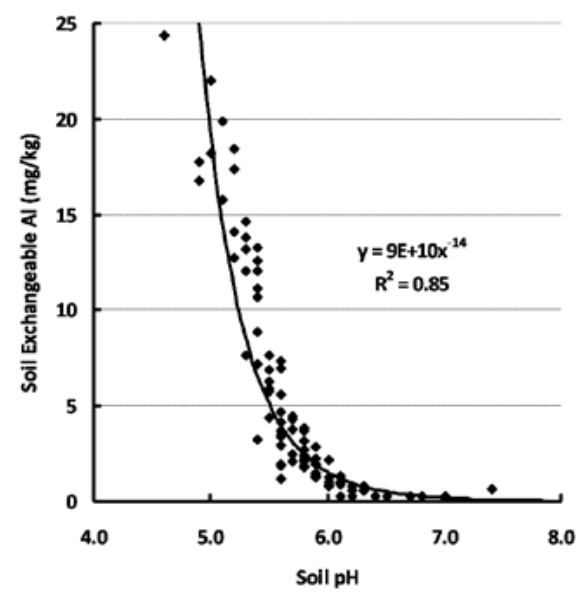

b

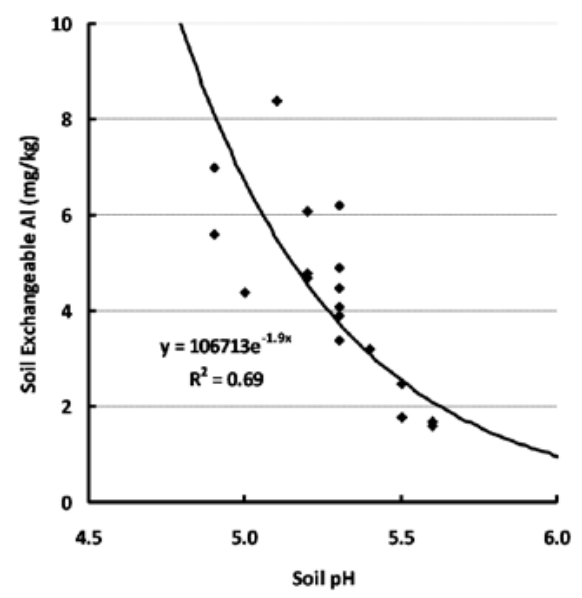

C

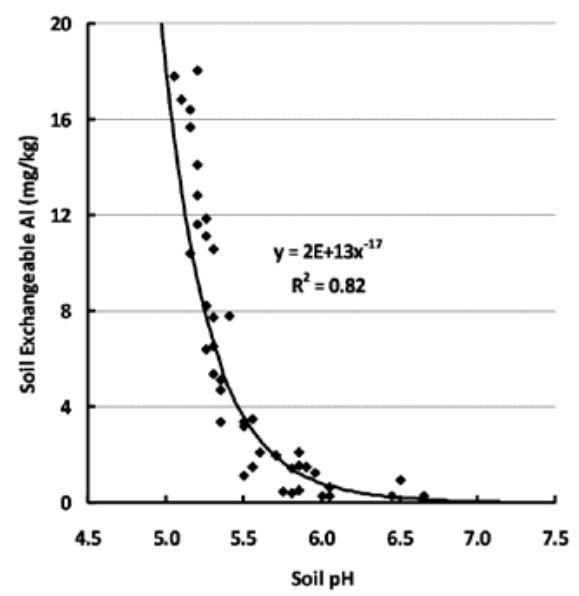

Figure 1 The relationships between soil $\mathrm{pH}$ and soil exchangeable $\mathrm{Al}$ at $\mathbf{a}$, Site 1 (Mt Pember station); b, Site 2 (Glenmore Station); and c, Site 3 (Glenfoyle Station).

\section{Lime effects on exchangeable aluminium concentrations}

Soil exchangeable Al concentrations were strongly affected by lime rate. Comparing the highest lime rate at each site, soil exchangeable Al dropped by $2.5,2.4$ and $2.0 \mathrm{mg} \mathrm{Al} / \mathrm{kg}$ at Sites 1,2 and 3, respectively for the $0-7.5 \mathrm{~cm}$ horizon. In the 7.5-15 $\mathrm{cm}$ horizon, changes in exchangeable $\mathrm{Al}$ concentrations were minimal, except at the oldest Site 3, where $4 \mathrm{t}$ lime/ha caused a reduction of $8.1 \mathrm{mg} \mathrm{Al} / \mathrm{kg}$.

\section{Relationships between soil $\mathbf{p H}$ and exchangeable aluminium}

Over all soil sampling depths and liming rates, soil $\mathrm{pH}$ was strongly associated with soil exchangeable Al concentrations at all sites (Figure 1). Exponential curves were appropriate to describe the relationships at sites $1\left(\mathrm{R}^{2}=0.85\right)$ and $3\left(\mathrm{R}^{2}=0.83\right)$, but a polynomial curve was required at site $2\left(\mathrm{R}^{2}=0.69\right)$. Soil exchangeable $\mathrm{Al}$ was low $(1-2 \mathrm{mg} / \mathrm{kg})$ within the soil $\mathrm{pH}$ range of 6.0-7.0. However, exchangeable Al concentrations rose sharply to $2-3 \mathrm{mg} / \mathrm{kg}$ when $\mathrm{pH}$ fell below 5.7 . At a $\mathrm{pH}$ of 5.5 , exchangeable $\mathrm{Al}$ increased to $5.0,2.5$ and $4.0 \mathrm{mg} / \mathrm{kg}$ at sites 1,2 and 3 respectively. Increases in exchangeable $\mathrm{Al}$ below $\mathrm{pH} 5.5$ were near linear at sites 1 and 3, increasing at 3-4 mg Al/ $\mathrm{kg}$ per $0.1 \mathrm{pH}$ unit decrease in $\mathrm{pH}$. At site 2, increases in exchangeable $\mathrm{Al}$ below $\mathrm{pH} 5.5$ were $1 \mathrm{mg} \mathrm{Al} / \mathrm{kg}$ per $0.1 \mathrm{pH}$ unit decrease in $\mathrm{pH}$.

\section{Discussion}

This study has determined the effects of historic liming on soil $\mathrm{pH}$ at three high country locations, and in turn, on exchangeable $\mathrm{Al}$, in two surface soil horizons. Strong relationships between soil $\mathrm{pH}$ and exchangeable plant-available $\mathrm{Al}$ were established for these soils, whereby soil exchangeable $\mathrm{Al}$ increased exponentially below a soil $\mathrm{pH}$ of 5.7. The "change points" on the curves for Sites 1 and 3 are strong evidence that these soils are very sensitive to $\mathrm{pH}$ change. Importantly, below $\mathrm{pH}$ 5.7, $\mathrm{Al}$ concentrations increase rapidly to values that are toxic to many legumes. This result generally agrees with that reported by Hochman et al. (1992) for three New Zealand Brown soils, but does not follow in soils of different age and mineralogy. For example, Mullen et al. (2006) reported low exchangeable $\mathrm{Al}$ of $1.3 \mathrm{mg} / \mathrm{kg}$ at $\mathrm{pH} 4.4\left(\mathrm{CaCl}_{2}\right)$ in a soil (Red Chromosol, granitic parent material) in New South Wales. Our results also highlight the problem of higher soil-exchangeable aluminium concentrations (at "typical" field soil pHs) in Brown soils, which are common to South Island high country. Also notewothy, is the variable relationship between soil exchangeable $\mathrm{Al}$ and soil $\mathrm{pH}$, and that relationships between these indices appear to be soil or site specific. Further detailed research is required to determine the key mechanisms driving the site-to-site variations in these relationships.

Liming had a strong medium-term effect on soil $\mathrm{pH}$ at all three sites, especially in the $0-7.5 \mathrm{~cm}$ soil horizon. Soil $\mathrm{pH}$ increased an average of 0.16 units/t lime applied. This result agrees with Wheeler \& Edmeades (1995) and Black \& Cameron (1984). Liming reduced soil exchangeable Al concentrations in the surface soil horizon by $2.0-2.5 \mathrm{mg} / \mathrm{kg}$, even $3-7$ years after application. This result demonstrates that exchangeable 
$\mathrm{Al}$ at the soil surface can be reduced to safe values, even several years after lime application. At a soil $\mathrm{pH}$ of 5.5 , exchangeable $\mathrm{Al}$ increased to $3.0 \mathrm{mg} / \mathrm{kg}$ or above. At this level, exchangeable $\mathrm{Al}$ is likely to reduce DM yield (Wheeler et al. 1992; Moir \& Moot 2010). Consequently, on-farm decisions on lime rates and legume species suitability need to be based on soil $\mathrm{pH}$ and $\mathrm{Al}$ testing from individual farm blocks rather than using "rule of thumb" approaches across farms.

The measurable effects of lime were less obvious in the deeper soil horizon, with only modest changes in soil $\mathrm{pH}$ and exchangeable Al. At site 1, lime at $8 \mathrm{t} /$ ha increased soil $\mathrm{pH}$ by about $0.5 \mathrm{pH}$ units in the 7.515 soil horizon, but lower lime rates had little effect. This increase in soil $\mathrm{pH}$ resulted in a corrresponding drop in exchangeable soil Al from 5.6 to $1.9 \mathrm{mg} / \mathrm{kg}$. Importantly, this reduction in $\mathrm{Al}$ represents a change to non-toxic concentrations in the $7.5-15 \mathrm{~cm}$ horizon at Site 1, 5 years after the initial application. This contrasts with no reduction in exchangeable Al being observed in earlier measurements at this site (Moir \& Moot 2010), and reinforces the importance of running trials for longer time spans to determine the longer-term effects of climate and its variability on the response to lime in these high country environments. Interestingly, no soil $\mathrm{pH}$ or $\mathrm{Al}$ changes occurred in the $7.5-15 \mathrm{~cm}$ horizon at Site 2 as a result of liming. This is the youngest site and mirrors the lack of response in this horizon previously seen at Site 1. Futher monitoring will continue at this site. The implication is that even at a rate of $5 \mathrm{t} / \mathrm{ha}$, surfaceapplied lime is unlikely to reduce plant-available soil aluminum to safe concentrations for legume growth in the $7.5-15 \mathrm{~cm}$ horizon at Site 2 within 3 years. Thus, the application of lime should occur prior to 3 years of winter forage, crops such as ryecorn, to break down the resident vegetation. However, even this may be insufficient to allow the successful establishment of aluminium senstive legumes, and alternatives such as Lupinus polyphyllus may be required (Moot \& Pollock 2014). As it stands, plant root depth and therefore available water content of the soil are likely be compromised at Site 2, which may impact on yield and persistence (Mullen et al. 2006; McGowan et al. 2003; Teixeira et al. 2006; Grewal \& Williams 2003). At Site $3, \mathrm{Al}$ concentrations were reduced to "safe" values $(<3$ $\mathrm{mg} \mathrm{Al} / \mathrm{kg}$; Moir \& Moot 2010) in the 0-7.5 cm horizon at lime rates of $1 \mathrm{t} / \mathrm{ha}$ and above. However, background Al were much higher in the $7.5-15 \mathrm{~cm}$ horizon at this site. Consequently, although $\mathrm{Al}$ was substantially reduced in the deeper horizon (again, by lime rates of $1 \mathrm{t} / \mathrm{ha}$ and above), $\mathrm{Al}$ concentrations were still around $10 \mathrm{mg} / \mathrm{kg}$, and so remained toxic to most pasture legumes. Ongoing research at Lincoln University is looking at the effect of incorporation of lime in cultivation or subsoil lime application so that soil $\mathrm{pH}$ is increased at depth. These very high $\mathrm{Al}$ concentrations in the $7.5-15 \mathrm{~cm}$ horizon at Site 3 contrast with those of the other two sites in this study, and highlight the variability of soil exchangeable $\mathrm{Al}$ due to site specific factors, which are currently poorly understood. This study has highlighted the importance of conducting longer-term soil measurements in order to develop a fuller understanding of the effects of lime. Repeated measurements in a time sequence are therefore required to improve our understanding. Ideally, further research is required to explain the key factors driving variability in soil exchangeable $\mathrm{Al}$ concentrations.

\section{Conclusions}

- Soil pH was strongly related to concentrations of soil exchangeable Al.

- Surface applied lime increased soil pH and reduced soil exchangeable aluminium, especially at higher lime rates.

- Surface applied lime took 5-8 years to produce observable changes in the $7.5-15 \mathrm{~cm}$ zone.

- The effect of lime on soil pH and exchangeable Al varied between sites, which highlights the lack of current understanding of mechanisms driving exchangeable $\mathrm{Al}$ concentrations.

- On-farm decisions on lime rates and legume species suitability need to be based on soil $\mathrm{pH}$ and $\mathrm{Al}$ testing from individual farm blocks rather than using "rule of thumb" approaches.

\section{ACKNOWLEDGEMENTS}

The authors thank Malcolm Smith, Keith Pollock, Dave Jack, Dan Dash, Saman Bernji and Travis RyanSalter for field assistance. This research was funded by Ballance Agri-Nutrients Ltd. and the New Zealand Merino Company Ltd.

\section{REFERENCES}

Black, A.S.; Cameron, K.C. 1984. Effect of leaching on soil properties and lucerne growth following lime and gypsum amendments to a soil with an acid subsoil. New Zealand Journal of Agricultural Research 27: 195-200.

Edmeades, D.C.; Smart C.E.; Wheeler, D.M. 1983. Aluminium toxicity in New Zealand soils: preliminary results on the development of diagnostic criteria. New Zealand Journal of Agricultural Research 26: 493-501.

Edmeades, D.C.; Blamey, F.P.C.; Asher, C.J.; Edwards, D.G. 1991. Effects of $\mathrm{pH}$ and aluminium on the growth of temperate pasture species. II. Growth and nodulation of legumes. Australian Journal of Agricultural Research 42: 893-900.

Espie, P. 2008. Glenfoyle lime trial 2005-2008. Commissioned report. $16 \mathrm{pp}$. 
Fasi, V.; Mills, A.; Moot, D.J.; Scott, W.R.; Pollock, K. 2008. Comparative growth forms of dryland forage legumes. Proceedings of the New Zealand Grassland Association 70: 123-130.

Grewal, H.S.; Williams, R. 2003. Liming and cultivars affect root growth, nodulation, leaf to stem ratio, herbage yield, and elemental composition of alfalfa on an acid soil. Journal of Plant Nutrition 26: 16831696.

Haynes, R.J.; Williams, P.H. 1993. Nutrient cycling and soil fertility in the grazed pasture ecosystem. Advances in Agronomy 49: 120-199.

Hochman, Z.; Edmeades, D.C; White, E. 1992. Changes in effective cation exchange capacity and exchangeable aluminium with soil $\mathrm{pH}$ in limeamended field soils. Australian Journal of Soil Research 30: 177-187.

Lanyon, L.E.; Griffith, W.K. 1988. Nutrition and fertilizer use. pp. 333-372. In: Alfalfa and alfalfa improvement. Eds. Hanson, A.A.; Barnes, D.K.; Hill, R.R. American Society of Agronomy, Madison, USA.

McGowan, A.W.; Sheath, G.W.; Webby, R.W. 2003. Lucerne for high quality summer feed in North Island hill country. Legumes for dryland pastures. Grassland Research and Practice Series 11: 169174.

Moir, J.L., Moot, D.J. 2010. Soil pH, exchangeable aluminium and lucerne yield responses to lime in a South Island high country soil. Proceedings of the New Zealand Grassland Association 72: 191196.

Moir, J.L.; Scotter, D.R.; Hedley, M.J.; Mackay, A.D. 2000. A climate-driven, soil fertility dependent, pasture production model. New Zealand Journal of Agricultural Research 43: 491-500.
Moot, D.J.; Pollock, K. 2014. Yield and botanical composition of lupins sown at different rates at Glenmore Station. New Zealand Journal of Agricultural Research 76: 53-59.

Mullen, C.L.; Scott, B.J.; Evans, C.M.; Conyers, M.K. 2006. Effect of soil acidity and liming on lucerne and following crops in central-western New South Wales. Australian Journal of Experimental Agriculture 46: 1291-1300.

Rechcigl, J.E.; Edmisten, K.L.; Wolf, D.D.; Renau, R.B. Jr. 1988. Response of alfalfa grown on acid soil to different chemical amendments. Agronomy Journal 80: 515-518.

Su, C.; Evans, L.J. 1996. Soil solution chemistry and alfalfa response to $\mathrm{CaCO}_{3}$ and $\mathrm{MgCO}_{3}$ on an acidic gleysol. Canadian Journal of Soil Science 76: 41-47.

Teixeira, E.I.; Moot, D.J.; Brown, H.E.; Fletcher, A.L. 2006. The dynamics of lucerne (Medicago sativa L.) yield components in response to defoliation frequency. European Journal of Agronomy 26: 394400.

Wheeler, D.M; Edmeades, D.C.; Christie, R.A.; Gardner, R. 1992. Effect of aluminium on the growth of 34 plant species: A summary of results obtained in low ionic strength solution culture. Plant and Soil 146: 61-66.

Wheeler, D.M; Edmeades, D.C. 1995. Effect of depth and lime or phosphorus fertilizer applications on the soil solution chemistry of some New Zealand pastoral soils. Australian Journal of Agricultural Research 33: 461-476. 